\title{
A Comparative Study of Tone of West Ugandan Bantu Languages, with Particular Focus on the Tone Loss in Tooro
}

\author{
Shigeki Kaji \\ Graduate School of Asian and African Area Studies, Kyoto University, Japan
}

\section{Introduction}

In Western Uganda, some closely related Bantu languages such as Ankole (J.13), Kiga (J.14), Tooro (J.12) and Nyoro (J.11) are spoken. These languages plus Haya (J.22) of Tanzania which is spoken to the south of Ankole are sometimes referred to as Kitara (using the old name of BunyoroKitara kingdom) as a group. However, when we look at the tone system of these languages, we easily notice some striking differences. The most particular is the fact that Tooro has completely lost its original lexical tone distinction, where the penultimate syllable of the word is always

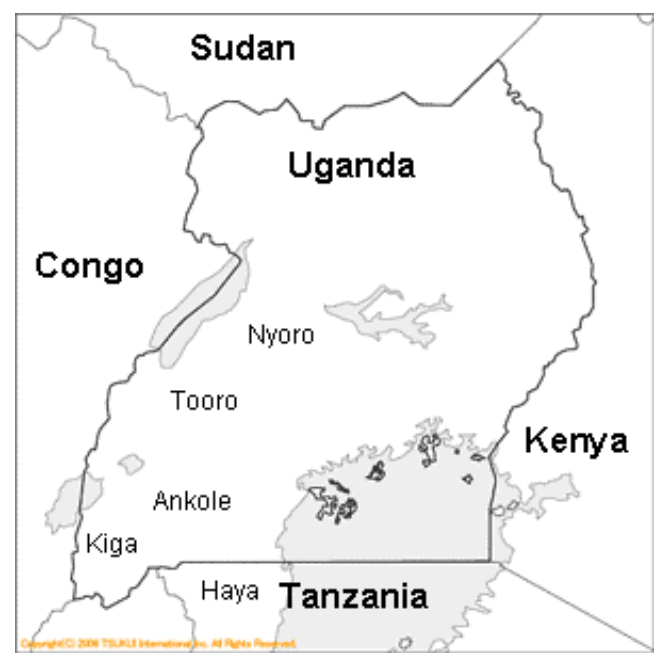

Figure 1: Location of the languages dealt with in this paper high-pitched in isolation, whereas Haya, and also Ankole to a certain point, retains a relatively old system, in which the disyllabic -HL, -LH and -LL noun stems are differentiated. Nyoro which is spoken to the north of Tooro shows an intermediate stage; it has two patterns only, namely penultimate high-toned (...HL) and final high-toned (...LH) patterns.

The aim of this paper is to try to explain how the Tooro system, which phonologically lacks tone, has come into being, by examining comparatively the tone system of each language itself and also by closely looking at the differences which exist among the Haya, Ankole and Nyoro systems (Kiga data insufficient) in order to look for phonetic reasons of the tone changes.

Generally speaking the tone system becomes simpler as we proceed from south to north. This may have relation to the fact that this group of Bantu languages is the northern most one of this area and to the north of it Nilotic languages like Acholi, Lango and Alur are spoken. In this paper, however, we 
will look for internal causes of tone simplification, putting aside external factors of language contact.

\section{Haya}

The characteristics of Haya tone include the following. ${ }^{1}$

1. The Haya tone system is the oldest among these languages.

2. There are words which have no high tone (...ss). ${ }^{2}$

3. If a word has high tone, it appears only in one syllable underlyingly (...sśssss, ...sśsss, ...sśss, ...sśs, ...sś).

4. Underlying distinctions are kept phonetically in isolation.

5. High tone in the ultimate syllable is anticipated by one syllable, and high tone in the penultimate syllable is realized falling in isolation.

6. When the possessive adjective -ange "my" qualifies a noun, a syntactic $\mathrm{H}$ is inserted.

The Haya tone and its phonetic realization are illustrated from (2.1) to (2.5). The nouns are arranged according to the length of the stem. A hyphen is inserted between the prefix and the stem in isolation forms. The tone bearing unit is the syllable. The noun forms are given in two ways, one as pronounced in isolation and the other in the construction with the qualifying possessive adjective -ange "my" which comes after the head noun. We note that this noun phrase construction reveals the underlying tone patterning which gets behind in isolation. The underlying high-toned syllable is underlined.

We notice that the number of patterns increases in function of the length of the stem. The pattern of the type ekí-laba 7,8 "species of tree", which has an underlying $\mathrm{H}$ in the prefix, is rare.

2.1. one-syllable stem words
a. omu-zi 3,4
root
cf. omuzí gwange 3 "my "
b. omú-ti 3,4
tree
cf. omutí gwange 3 "my "

2.2. two-syllable stem words
a. omu-nofu 3,4
flesh
cf. omunofú gwange 3 "my "
b. eki-zíla 7,8
prohibition
cf. ekizilá kyange 7 "my "
c. omu-kâma 1,2
king
cf. omukáma wange 1 "my "
d. ekí-laba 7,8
species of tree
cf. ekílabá kyange 7 "my "

See Byarushengo et al. (1976) and Kaji (2000) for more details.

2 Here "s" stands for syllable. 
2.3. three-syllable stem words
a. omu-guruka 3,4
snare trap
cf. omuguruká gwange 3 "my "
b. aka-ningíli 12,14
lute
cf. akaningilí kange 12 "my "
c. omu-gurûsi 1,2
old man
cf. omugurúsi wange 1 "my $\sim$ "
d. eki-kójozi 7,8
plantain
cf. ekikójozí kyange 7 "my "

2.4. four-syllable stem words
a. eki-gendelelo 7,8 intention
cf. ekigendeleló kyange 7 "my "
b. eki-kankabána 7,8
male bud of cf. ekikankabaná kyange 7 "my " banana tree
c. eki-nu:manûmi 7,8 shadow
cf. ekiju:manúmi kyange 7 "my "
d. olu-julúluzi 11,10 species of tree cf. olujulúluzí lwange 11 "my "
e. eki-kálakamba 7,8 scale cf. ekikálakambá kyange 7 "my "

2.5. five-syllable stem words

a. em-puru:tulilo 9,10 loose knot cf. empuru:tuliló yange 9 "my "

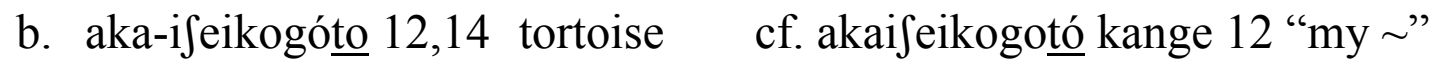

c. VCV-CVCVCVCVCV no examples

d. VCV-CVCVCV́CVCV no examples

e. VCV-CVCV́CVCVCV no examples

f. oku-búnda:miliza 15 stooping (to serve tea) cf. okubúnda:milizáa kwange 15 "my $\sim$

\section{Ankole}

The Ankole system basically remains the same as the Haya system, but has moved one step or two toward tone simplification. The characteristics of Ankole tone include the following.

1. As far as the system is concerned the Ankole tone system is the same as the Haya system.

2. There are words which have no high tone (...ss).

3. If a word has high tone, it appears only in one syllable underlyingly (...sśssss, ...sśsss, ...sśss, ...sśs, ...sś).

4. Underlying distinctions are generally kept in isolation except in one pattern. That is, although when a word's penultimate syllable is long and $\mathrm{H}$-toned, this $\mathrm{H}$ is realized as $\mathrm{F}$ (falling) like Haya, when a word's penultimate syllable is $\mathrm{H}$-toned but short, this underlying $\mathrm{H}$ is realized as $\mathrm{H}$, and not $\mathrm{F}$ like Haya, thus confusing the ...HL pattern with the ...LH 
patterns in isolation. Both become ...HL. See (3.6) for examples of Htoned long penultimate syllables.

5. In the noun phrase construction with the possessive adjective -an/e "my", a syntactic $\mathrm{H}$ is inserted only when the noun has no high tone, thus avoiding low flat configurations.

6. In a number of words high tone is lost in comparison with Haya.

3.1 one-syllable stem words
a. omu-zi 3,4
root
cf. omuzí gwanje 3 "my "
b. omú-si 3,4
vein, nerve
cf. omusí gwanje 3 "my "

3.2. two-syllable stem words
a. omu-hara 1,2
daughter
cf. omu-hará wanfe 1 "my "
b. ama-ríra 6
mourning
cf. amarirá ganfe 6 "my "
c. omu-káma 1,2
king
cf. omukáma wanfe 1 "my "

3.3. three-syllable stem words
a. aka-gobora 12,14
elephant tusk cf. akagoborá kanłe 12 "my "
b. eci-tentére 7,8 young hen cf. ecitenteré canfe 7 "my $\sim$ "
c. oru-tongána 11,10 index finger cf. orutongána rwanfe11 "my "
d. aka-tádoba 12,14 hand-made lamp cf. akatádoba kanje 12 "my "
e. ebí-runfire 8 sauce cf. ebírunfire byanje 8 "my "

3.4. four-syllable stem words
a. aka-hungabebe 12,14 termite
cf. akahungabebé kanje 12 "my "
b. oru-to:jeréra 11,10 drizzle cf. oruto:nererá rwanje 11 "my "
c. aka-samuníga 12,14 skunk cf. akasamuníga kanfe 12 "my "
d. eci-gungúniro 7,8 threshed corncob cf. ecigungúniro canfe 7 "my "
e. eci-sífisiro 7,8 small clay pot cf. ecisífisiro canfe 7 "my small "

3.5. five-syllable stem words
a. oku-si:tagirira 15 crashing with feet
b. VCV-CVCVCVCV́CV cf. okusi:tagirirá kwanłe 15 "my "
c. $\mathrm{VCV}-\mathrm{CVCVCVCV́} \mathrm{CV}$ no examples
d. VCV-CVCVCV́CVCV no examples
e. VCV-CVCV́CVCVCV no examples
f. en-tá:gurukane 9,10 no examples crossroads cf. entá:gurukane yanfe 9 "my "

3.6. words with a H-toned long penultimate syllable
a. eci-ł̂̂kko (*eci-łílko) 7,8
spoon
cf. ecifíkko canje "my " 

b. eci-tộ:ma (*eci-tó:ma) 7,8
bark cloth
cf. ecitó:ma canje "my "
c. e-tûitu (*e-túitu) 9,10
sweat
cf. etú:tu yanje "my $\sim$

\section{Tooro}

The characteristics of Tooro tone include the following.

1. Tooro has lost its lexical tone. ${ }^{3}$ All nouns are pronounced with high tone on the penultimate syllable in isolation (..sśs).

2. $\mathrm{H}$ tone in isolation disappears when the noun is followed by the possessive adjective -ánge "my", which has a high tone.

4.1. one-syllable stem words

$\begin{array}{lll}\text { omú-twe } 3,4 & \text { head } & \text { cf. omutwe gwánge } 3 \text { "my " } \\ \text { omú-ti } 3,4 & \text { tree } & \text { cf. omuti gwánge } 3 \text { "my " }\end{array}$

4.2. two-syllable stem words

omu-kázi 1,2 woman, wife cf. omukazi wánge 1 "my "

oku-gúru 15,6 leg cf. okuguru kwánge 15 "my "

4.3. three-syllable stem words

omu-gurúsi 1,2 old man cf. omugurusi wánge 1 "my "

omu-sigázi 1,2 male youth cf. omusigazi wánge 1 "my "

4.4. four-syllable stem words

omu-role:rézi 1,2 bishop cf. omurole:rezi wánge 1 "my "

aka-sirimúko 12,14 downhill slope cf. akasirimuko kánge 12 "my "

4.5 five-syllable stem words

obu-juna:nizíbwa 14 responsibility cf. obujuna:nizibwa bwánge 14 "my " en-konkomerézi 9,10 woodpecker cf. enkonkomerezi yánge 9 "my "

\section{Nyoro}

The characteristics of Nyoro tone include the following.

1. Nyoro has two tone patterns underlyingly regardless of the length of the word (...sśs, ...sś), namely $\mathrm{H}$ either in the penultimate or ultimate syllable. The underlying High tone is realized falling in isolation.

3 Tone still fulfills grammatical functions in Tooro. See Kaji (2009). 
2. There are no low flat words (...ss).

3. The underlying $\mathrm{H}$ is realized as $\mathrm{F}$ in isolation. ${ }^{4}$

4. High tone anticipation is remarkable. ${ }^{5}$

5. The underlying $\mathrm{H}$ and the anticipated $\mathrm{H}$ remain $\mathrm{H}$ even when followed by the possessive adjective -ánge "my", which has a high tone.

5.1. one-syllable stem words
a. omú-tî̀ 3,4
tree
cf. omútí gwânge 3 "my "
b. obû-ne 14
liver
cf. obúne bwânge 3 "my "

5.2. two-syllable stem words
a. eki-gérê 7,8
foot
cf. ekigéré kyâge 7 "my "
b. ama-zîga 6
tears
cf. amazíga gânge 6 "my "

5.3. three-syllable stem words
a. obu-horókô 14
chicken lice
b. omu-gúrûsi 1,2
old man
cf. obuhorókó bwânge 14 "my "
cf. omugúrúsi wânge 1 "my "

5.4. four-syllable stem words
a. e-namunúngû 9,10 porcupine
cf. ejamunúngú yânge 9 "my "
b. oru-kanakâna 11,10 dewdrop cf. orukanakána rwânge 11 "my "

5.5. five-syllable stem words
a. aka-gongabahárâ 12,14 wagtai. cf. akagongabahárá kânge 12 "my "
b. eki-tabujúgûta 7,8 species of civet cf. ekitabujúgúta kyânge 7 "my "

\section{Comparison of Haya, Ankole, Nyoro and Tooro}

There are several patterns of tonal correspondence among Haya, Ankole and Nyoro, but the following three from (6.1) to (6.3) with examples of two-syllable stem nouns are the most numerous. Note that whereas the original patterns -HL and -LH are kept differentiated in Nyoro, the -LL pattern has received high tone on the penultimate syllable, a default position in Bantu (?). The result is that there are only two patterns in Nyoro, namely the -HL pattern and the -LH pattern.

4 In some words this falling is hardly heard.

5 The exact nature of high tone anticipation remains to be determined. 
Haya Ankole Nyoro Tooro

6.1. $\begin{array}{llll}\text {-HL } & \text {-HL } & \text {-HL } & \text {-HL }\end{array}$
a. amazîga 6 amazíga 6
amazîga 6
amazíga 6
tears
b. olulîmi 11,10 orurími 11,10
orulîmi 11,10
orulími 11,10
tongue
c. embûzi 9,10 embúzi 9,10
embûzi 9,10
embúzi 9,10 goat

6.2 .

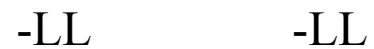

$-\mathrm{HL}$

$-\mathrm{HL}$

a. omumiro 3,4 omumiro 3,4

omúmîro 3,4

omumíro 3,4 throat

b. ekinoni 7,8 ekinoni 7,8

ekinôni 7,8

ekinóni 7,8 bird

c. enama 9,10 enama 9,10

enâma 9,10

enáma 9,10 meat

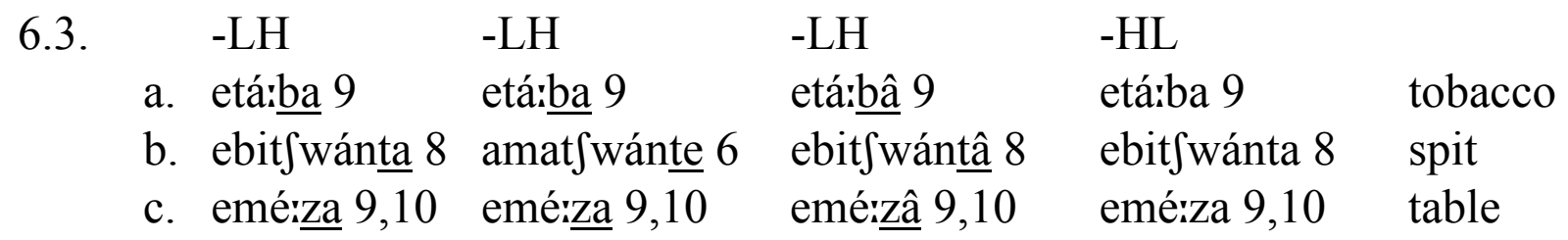

As for patterns with an original high tone before the antepenultimate syllable, we note that high tone has moved to the penultimate syllable of the word. This also confirms the fact that Nyoro has only two patterns, ...HL and ...LH.
Haya
Ankole
Nyoro
Tooro

6.4 .

...HLL

...LHL

...LHL

a enkókola 9,10 enkókora 9,10 enkókôra 9,10 enkokéra 9,10 elbow

b. omutábani 1,2 omutábani 1,2 omutábâni 1,2 omutabáni 1,2 son

c. omusígazi 1,2 omusígazi 1,2 omusígâzi 1,2 omusigázi1,2 male youth

6.5 ...HLLL ...HLLL ...LLHL ...LHL

a. oruzíramere 11,10 enzirámîra 9,10 enzirmíra 9,10 python

b. ekikálakamba 7,8 ekigaragâmba 7,8 (ekikaraká:ta 7,8) scale

There are other types of correspondence among Haya, Ankole and Nyoro, like those listed from (6.6) to (6.9) though their examples are not numerous. The examples in (6.6) are a different development from those in (6.1) in which Nyoro reflexes are -HL. Also, the examples in (6.7) show a different development from those in (6.2) in which Nyoro reflexes are -HL. The examples in (6.8) and (6.9) indicate that it is rather Ankole which has deviated from the normal development. It is of particular interest to note that in (6.8) Ankole has lost $\mathrm{H}$ in words in which Haya and Ankole have $\mathrm{H}$. We also note that in all these examples Nyoro reflexes are the -LH pattern. 


\begin{tabular}{|c|c|c|c|c|c|}
\hline & Haya & Ankole & Nyoro & Tooro & \\
\hline 6.6. & $-\mathrm{HL}$ & $-\mathrm{HL}$ & $-\mathrm{LH}$ & $-H L$ & \\
\hline & a. ekijîk 7,8 & ekiłî:ko 7,8 & ekijíkô 7,8 & ekigíḱo 7,8 & spoon \\
\hline & b. engâta 9,10 & engáta 9,10 & engátâa 9,10 & engáta 9,10 & headpad \\
\hline & c. ekitêbe 7,8 & ekitébe 7,8 & entébê 9,10 & entébe 9,10 & chair \\
\hline
\end{tabular}

6.7

$\begin{array}{rlllll} & \text { LL } & \text {-LL } & \text {-LH } & \text {-HL } \\ \text { a. } & \text { olugino 11,10 } & \text { engino 9,10 } & \text { engúnû 9,10 } & \text { engúnu 9,10 } & \text { gum } \\ \text { b. } & \text { omuguwa 3,4 } & \text { omuguha 3,4 } & \text { omugúhâ 3,4 } & \text { omugúha 3,4 } & \text { rope } \\ \text { c. } & \text { oluba:o 11,10 } & \text { ruba:ho 11,10 } & \text { rubá:hô } 11,10 & \text { rubá:ho 11,10 board, } & \text { blank, timber }\end{array}$

6.8. $-\mathrm{LH}$

$-\mathrm{LL}$

-LH

$-\mathrm{HL}$

a. omuhára 1,2

omuhara 1,2

omuhárâ 1,2

omuhâra 1,2

daughter

b. ekigéle 7,8

ekifere 7,8

ekigérê 7,8 ekigêre 7,8

foot, sole

c. empúnu 9,10

empunu 9,10 empúnû 9,10 empúnu 9,10

pig

6.9.

$-\mathrm{LH}$

a. engége 9,10

$-\mathrm{HL}$

-LH

$-\mathrm{HL}$

b. ekifúfu 7,8

enféfe 9,10

engégyê 9,10

engége 9,10 tilapia

ekifúfu 7,8

ekisúsûu 7,8

ekisúsu 7,8 bark

c. eikópo 5,6

ekikópo 7,8

ekikópô 7,8

ekikópo 7,8 cup

\section{Step from Nyoro to Tooro}

As we confirmed in the previous section, Nyoro has only two patterns: ...HL and ...LH. Only one step is necessary to arrive from the Nyoro stage at the Tooro stage, which always has high tone in the penultimate syllable in isolation, namely merger of the ...HL and ...LH patterns. This merger must have happened by changing the ...LH pattern to the ...HL pattern. This may happen without much difficulty if we consider the phonetic realizations of these two patterns. The ...LH pattern, which is realized as ...HF in isolation in Nyoro, is sometimes heard as ...HL, and in fact it is ...HL in Ankole. The ...HL pattern is realized as ...HF in isolation in Nyoro but sometimes heard as ...HL and it is ...HL in Ankole in isolation when the H-toned syllable is a short one. 


\section{Summary by way of conclusion}

In Haya, with the oldest system, the underlying ...LH and ...HL patterns are differentiated even in isolation, but the difference between their respective phonetic realizations ...HL and ...FL is slight (see for example, 2.2.b. eki-zíla 7,8 "prohibition" and 2.2.c. omu-kâma 1,2 "king"). In Ankole, these two patterns are differentiated underlyingly as in Haya, but when the penultimate H-toned syllable is short they are pronounced in the same way in isolation (see for example 3.2.b. ama-ríra 6 "mourning" and 3.2.c. omu-káma 1,2 "king").

In Nyoro we note one big change, namely that all the patterns except the ...LH have become ...HL (except some exceptions). In particular the ...LL pattern has become ...HL (cf. 6.2), with the result that Nyoro has only two patterns, which are ...HL and ...LH. The Tooro state can be reached by one step from Nyoro by changing the underlying ...LH to ...HL. This change must have been realized without much difficulty if we consider the subtlety of the phonetic difference between these two patterns, namely ...FL and ...HF in Nyoro and the sameness in Ankole, both being ...HL

\section{References}

Byarushengo, Ernst Rugwa, Larry M. Hyman and Sarah Tenenbaum (1976). Tone, Accent, and Assertion in Haya. In: Hyman L.M. (ed.). Studies in Bantu Tonology, Southern California Occasional Papers in Linguistics 3: 183-205.

Kaji, Shigeki (2000). A Haya Vocabulary. Institute for the Study of Languages and Cultures of Asia and Africa, Tokyo University of Foreign Studies.

Kaji, Shigeki (2004). A Runyankore Vocabulary. Research Institute for Languages and Cultures of Asia and Africa, Tokyo University of Foreign Studies.

Kaji, Shigeki (2007). A Rutooro Vocabulary. Research Institute for Languages and Cultures of Asia and Africa, Tokyo University of Foreign Studies.

Kaji, Shigeki (2009). Tone and syntay in Rutooro, a toneless Bantu language of Western Uganda, Language Sciences 31 (2-3): 239-247.

Kaji, Shigeki (in preparation). A Runyoro Vocabulary. 